\title{
RACING THE NATION
}

Colour-Coded: A Legal History of Racism in Canada, 1900-1950, Constance Backhouse (Toronto: University of Toronto Press, 1999)

Radio Free Dixie: Robert F. Williams \& the Roots of Black Power, Timothy B. Tyson (Chapel Hill \& London: University of North Carolina Press, 1999)

Stirrings in the Jug: Black Politics in the Post-Segregation Era, Adolph Reed, Jr. (Minneapolis: University of Minnesota Press, 1999)

In the United States few would argue that race is not a central divide, cutting through almost all aspects of social, economic, and cultural life, and drawing a line in the political sand of civil society. For Canadians, the realities of race have, supposedly, been more obscured. These realities are hidden in histories that mythologize marginalization and that wash partially clean the blood-stained record of violence long waged against those marked by the arbitrary, historically-contextualized codes of racialized 'colour': white vs nonwhite. Yet race, for all its mysticized social construction, is increasingly recognized as a potent factor in Canada's past, precisely because it is a troubling 'problem' in our present. "Racing the nation" means acknowledging the powerful continuities, not in the pseudoscientific biological distinctions of census-taking and physiological difference, but in the historically-embedded racisms that have articulated whiteness as power, and the practices that flow from this, segmenting society in diverse ways. The disparate subterranean streams that flow from this process have fed, over the centuries, a common well of racism. Out of this well institutions and individuals have quenched their thirst for order, progress, and democracy in poisonous, if often unappreciated, rationalizations of brutalizing inequality.

Constance Backhouse is one of Canada's finest historians on the subject of inequality. In the past her work has done a great deal to problematize the difference of gender, exploring the relationships of women and the law in nineteenth-century Canada. Recently she has turned her attention to racism and the law in the first half of the twentieth century. Her fine research skills, her impassioned prose, and her capacity to translate case law into narratives of contextualized social history will insure that Colour-Coded is both widely read and influential.

Backhouse, who has researched thousands of cases relating to race (which was not a legal category in the period studied), made the decision to structure her book around six particular litigations. These six litigations were chosen because they represent transformative and defining moments in the ostensibly undeclared law of race; because they provoke particular interest among subordinated, racialized groups of Canadians (some of whom attempted to use the law to challenge racist mechanisms that constrained their behaviour); and because they provide a sample of the regional diversity of racism in Canada. The cases she studies involve the legal prohibition of aboriginal dance in Manitoba in 1903; a 1921 First Nations' sovereignty claim in Ontario; the complex issue of race designation as it was fought out in a 1939 Supreme Court of Canada decision as to whether Inuit peoples were "Indian"; an Asian-Canadian's opposition to racially- 
gendered employment law in 1920s Saskatchewan (whereby "white" women were prohibited from working in establishments owned or managed by "any Japanese, Chinaman, or other Oriental person"); a 1930 prosecution in Oakville, Ontario of a Ku Klux Klan cross-burning and kidnapping aimed at breaking up a "mixed-race" sexual liaison; and a 1946 theatre-segregation case in Halifax.

Backhouse explores all of the cases with sensitivity. If there were Canadians who recognized racism and challenged the inequalities and intimidations that flowed from it, the ultimate structural power of the courts and the majesty of the law worked routinely and incessantly to overwhelm such interventions in what Backhouse (borrowing a phrase from the African-Canadian feminist Dionne Brand) calls a "stupefying innocence." It is possible to glimpse in this "innocence" of "racelessness" the weighty significance of gender and class. Many of the cases congeal the racial power of whiteness, the patriarchal authority of males, and the persistent significance of property and its lucrative markets. If race emerges as the always malleable category in these cases, its discursiveness usually manages to serve identifiable interests.'

Backhouse's method, while opening up specific cases to a narrative presentation of clarifying elegance, tends to telescope the history of racism in Canada in a somewhat simplifying focus, a reductionism accentuated by the limitations of the legalistic terrain on which she often walks. (Admittedly, Backhouse is quite wide-ranging compared to most legal scholars, and often brings into her argument social and political references many in the legal field would consider extraneous.) It would be both wrong and unfair to chastise Backhouse for such choices, for the subject matter is critically important. No one would deny that the law and the specific exemplary cases are windows of analytic opportunity into the history of race and racism in Canada. Moreover, Colour-Coded will stand for some time, and justifiably so, as a major text that reaches across disciplinary boundaries to address race and racism in Canada. But precisely because the book will undoubtedly attain this stature, it is important to illuminate its weaknesses. Her case study approach tends to freeze the moving frames of racism's Canadian history, and perhaps also to typecast them in specific, albeit unintended, ways. This problem is exacerbated by Backhouse's understandable reluctance to attempt to draw together any large analytic strands from the thousands of cases she has explored - a daunting task, to be sure which means that she stays relatively close to her material, but largely in a descriptive sense. Seldom does Backhouse offer readers much in the way of analytic abstraction in terms of the law's relation to equality in a bourgeois democratic order, commenting on its place in ensembles of power that link ideology and income, state, and subordination.

Ironically, these absences may perhaps undercut Backhouse's attempts to race the peculiarities of the Canadian nation. She suggests that it is the racelessness of Canadian law that lies at the core of the country's peculiarly suffocating ideology of "innocence." This is intriguing. As a gesture toward comparative history, this proposition rests on the conceptual assumption that there is nothing materially different in our nation's experience with race and racism than comparable experiences in, for example, the US. In obscuring 
that commonality of experience, Canada's national identity rests in part on the artifice of racelessness.

The problem with these propositions is twofold. First, they never proceed from a rigorous appreciation of national contexts. Second, they essentialize national difference, and in doing so play into, and feed off of, the standard mythologies of thoroughly conventional historiographies, all of which grew out of analytic frameworks and specific contextualized origins that purposefully mystified power and its meanings in terms of race, class, and gender. Backhouse's case studies relating to aboriginal law - comprising 50 percent of her examination of specific litigation - manage to set the history of Canadian First Nations into courtroom scenarios involving suppression of ritualistic dance and fishing rights, and anthropological/legal understandings of "race" groupings. No doubt American legal scholars could come up with similar cases. For all the seeming differences between Canadian and American treatment of native peoples over the course of the nineteenth century (in which the latter is known for its genocidal "Indian campaigns"; the former for its treaties and reserve system), there is enough in common in their seventeenth, eighteenth, and twentieth century histories of native-white contact, aboriginal dispossession, and modern marginalization to suggest that placing an emphasis on Canada's distinctiveness is perhaps to overdraw the difference in ways that obscure history's movements. Surely, with respect to aboriginal peoples and their racist subordination, the law is a legacy of a complex series of coercions and conquests, alliances and accommodations. In this series native peoples on both sides of the 49th parallel came out the losers to an interlocking set of market economies that, over time, knit themselves into regional blocs that eventually formed complicated, and always fissured, national identities. Within these histories, often rooted in contexts that preceded national/state formation, the diversity of racial subordination was paramount, but always within a systematic development of white settler Eurocommercial dominance. It is difficult to see, in three of Backhouse's case studies relating to aboriginal peoples, ${ }^{2}$ just how "racelessness" and "stupefying innocence" were peculiarly Canadian ideological responses that differed dramatically from what might have played out in the US. And certainly the cases of anti-Asian legislation, detailed not just in the curbs on female employment that are central to Backhouse's specified case, but in a rash of other racist law and practice common in Canada from the 1880 s on, are hardly examples of a peculiarly Canadian raceless innocence.

Backhouse's last two cases deal with the racism directed at, and challenged by, two Canadians of colour. ${ }^{3}$ In the first case, Backhouse explores the legal reaction to KKK vigilantism in a 1930 legal proceeding growing out of a mob attack on a "black" man living with a white woman. "Racelessness" and "stupefying innocence" do indeed seem appropriate characterizations of the court case. In this first KKK trial in Canada, four racist vigilantes were charged with the rather benign crime of "being disguised at night." Only the leader, Dr. William A. Phillips, a Hamilton chiropractor, was convicted. The Crown was satisfied with a $\$ 50$ fine, and did not even call for a mandatory prison term. 
Moved by arrogance, Phillips appealed, only to have the fine struck down and a prison term of three months imposed. Even the malleability of "race" categorization was evident in the trial and its aftermath as the "black" man in question claimed an aboriginal/white, rather than African-Canadian, identity. This positioning seemed to ease the way for his marriage to the white woman that the KKK had so ardently sought to free from his miscegeneous grasp.

In the final case explored in Colour-Coded, Backhouse examines Viola Desmond's challenge of the "colour-bar" segregation of seating at a Halifax theatre. An AfricanCanadian businesswoman, Viola Desmond found herself before the courts, charged with violating a provincial Amusements Tax Act. Following her conviction, Desmond filed a civil suit against the theatre and its manager. In the end, in what is a striking confirmation of Backhouse's interpretive stress on legalistic "racelessness" and "stupefying innocence," the courts ended up embroiled in a truly byzantine digression. This was occasioned in part by Desmond's lawyer's failure to confront the issue of race segregation head on. The outcome was an exercise in obfuscation, and one that ended with the frustrating refusal of the judges to address racial inequality and to overturn Desmond's conviction.

If these latter cases seem to confirm Backhouse's analytic stress on the ideology of legal "racelessness," they highlight racism in Canada in particular ways. To be sure, Backhouse's account of the Oakville KKK trial manages to convey the depth of Klan activity in Ontario in the 1920s. The conviction secured against Phillips, and the conventional wisdom that this judicial act drove the Klan into retreat, portrays the tradition of vigilante racism as somewhat weak in its commitment to violent disciplining of racial transgressions, and rather easily shaken in its racist resolve, at least in so far as this is compared with Klan activities in the US south. The theatre segregation case and its consequent legal fiasco, lay great stress on the symbolic confrontation waged by the most privileged segments of the African-Canadian community.

Two recent studies of the African-American political struggle highlight the possibility of different perspectives. Timothy B. Tyson's account of the life of a Monroe, North Carolina militant integrationist, Robert $\mathrm{F}$. Williams, portrays the racist violence that southern blacks faced on a daily basis.' Tyson shows how Williams drew on family traditions reaching back to the immediate post-Civil War era to develop a strategy of armed black self-defence. This self-defence challenged the KKK, the courts, and the police, as well as the emerging civil rights leadership associated with Martin Luther King and with nonviolence. In his uncompromising refusal to live in fear of a campaign of brutalizing, murderous white terror, Williams struggled to integrate pools and picnic sites, fought for jobs for blacks, praised white employers who hired African-Americans, and organized black defence guards to protect targeted civil rights advocates and his own family. Often appearing before the courts, and often threatened by police and by judges, Williams led many struggles that left no legal record. This is precisely because constituted authority either refused to recognize his reports of violence, or backed off its own path of official intimidation in the face of Williams' demonstrated willingness to offer armed 
resistance. Eventually forced to flee to Cuba, where he broadcast his "Radio Free Dixie" program, Williams was an anti-racist campaigner who bridged the chasm separating the civil rights struggles and black trade union activism of the 1940s and 1950s from the Black Power militancy of the 1960s.

Picking up in the mid-1960s where Williams left off, Adolph Reed, Jr. provides a set of sophisticated theoretical essays on black politics in the last decades of the twentieth century. ${ }^{6}$ Reed's essays are sensitive to the tensions in black political thought, especially those turning on the clash between black nationalism and class-based, Marxist appreciations of African-American oppression. Reed discusses how the militancy of the 1960s was demobilized, displaced in incorporations of the black political elite, or sidetracked in the inability of black intellectuals to grapple with the revived climate of racially-orchestrated antagonism. This was evident in the debates over the urban "underclass" or in the cultural commodification of representations of black militancy exemplified in the marketing of Malcolm X.

Books like those written by authors Tyson and Reed are in some ways a challenge to Backhouse's tendency, inherent in the reliance on exemplary case studies, to homogenize racism and resistance to it. They also both confirm and unsettle her suggestive construction of the particularities of Canada's history of legal racism turning on "racelessness" and "stupefying innocence." Certainly the Monroe County judge, who sentenced two pre-teenage black boys to long reformatory sentences for playing kissing games with white girls, basing his sentencing on what he termed "separate but equal" interrogations with whites and blacks in his chambers, ${ }^{7}$ was practicing a "raced" law that Backhouse gives little indication ever existed in Canada. Had the Oakville Klansmen run into Robert F. Williams, they would have faced more than a benign court intent on making a token conviction for going about "disguised at night."

Backhouse's Colour-Coded is to be commended for bringing us into the raced history of the nation. How complicated that history is, and what its analytic meanings and political complexities involve, as Backhouse herself acknowledges, awaits further histories of the raced pages of Canada, where white background often obscures words and other codes of colour.

\author{
Bryan D. Palmer \\ Department of History \\ Queen's University
}

